\title{
EFFECT OF INTERSTOCK ON GROWTH AND LEAF MINERAL CONTENT OF NAVEL ORANGE TRANSPLANTS
}

Marwa M. Yahia1, El wakeel H.M², Samaan M.S.F. ${ }^{2}$ and Elgamaal O.H. ${ }^{1}$

1. Plant Production Dept., Desert Research Center, Cairo, Egypt

2. Horticulture Dept., Fac. of Agric., Ain Shams Univ., P.O. Box 68, Hadayek Shobra 11241, Cairo, Egypt

*Corresponding author: marwayehia83@gmail.com

Received 27 February, 2019, $\quad$ Accepted 2 April, 2019

\begin{abstract}
Two famous Citrus rootstocks sour orange ( $C$. aurantium.) and volkamer lemon (C. volkamariana.) were tested as interstocks at the stage of transplant production to investigate their mutual effects on the scion growth characteristics, mineral content, carbohydrates, total indols and phenols from side; and rootstock growth traits. nitrogen content, carbohydrates, indols and phenols from the other side. Also the results indicated that Navel orange budded on $C$. volkamariana grafted on $C$. volkamariana achieved significantly the highest scion height, root length, leaf number. The highest content of $\mathrm{N}, \mathrm{P}, \mathrm{K}, \mathrm{Mg}$, Fe, $\mathrm{Zn}, \mathrm{Mn}$ and total phenols in scion stem. Moreover, the mentioned treatment gained the highest significant carbohydrates in roots.
\end{abstract}

Key words: Interstock, Rootstock, Navel orange, Citrus transplant, Sour orange, Volkamer lemon.

\section{INTRODUCTION}

Citrus is one of the most important fruit crops, which occupies the first rank in the production of fruit in Egypt. Citrus fruits represent $30 \%$ fruit of the production in Egypt with a capacity of 6.5 million tons and export 1.5 million tons according to The Agricultural Crops Export Council of Egypt (2017). Orange is the most productive member of Citrus species.

The common way of propagation in Citrus is grafting, which takes place in the spring, the selection of the rootstock has important effect on the behavior of scion including the vegetative characters, yield and fruit quality (Sharma et al 2016 and Manal Abo-Eid et al 2017)
Sour orange rootstock is the predominant in the clay heavy soil, semi dwarf, resistant to Phytophthora infection, the scions grafted on it produce high quality, juicy, smooth and thin skinned fruits also have deep root system (Manal Abo-Eid 2010). It has few compatibility with some Citrus varieties (Castle 2010).

Volkamer lemon rootstock has a strong growth and grow well insandy soil and yields high yield. Tolerant to Tristesza, Exocortis and Xyloporosis (Shafieizargar et al 2012). Tolerant to flooding (Protopapadakis et al 1998) it produced the most vigorous tree growth for Citrus cultivars (Khankahdani et al 2006 and Bassel, 2008)

Navel Orange is the most important cultivar because it haseconomic importance at the local market and export. Also, it isthe most popular cultivar in Egypt, the best taste, medium to medium large size fruit, seedless, gave high juicy, low thickness peel, smooth, sweet flavor and harvest on November to march (Ferguson, 2014).

Interstock originally used to overcome the problem of local incompatibility in grafting in several cases of fruit species (Hartmann et al 2014), In different cases, interstock may be used for its mutual effects on both scion and rootstock that could be useful in Citrus species (Gimeno et al 2012 and Kamilogu et al 2014)

In this study, sour orange and volkamer lemon genotypes at the transplant production stage were used as interstocks and rootstocks, alternatively, to take advantage of the distinctive qualities of both rootstocks and their effect on scion. Also, we aimed to appoint the effect of interstocks (sour orange and volkamer lemon) on vegetative growth and leaf mineral content of Navel orange scion. 


\section{MATERIALS AND METHODS}

The present study was carried out in saran house of Desert Research Center Ministry of Agriculture and Land Reclamation, El Matariya, Cairo, Egypt during 2014 to 2017 seasons. The genotypes which used as rootstocks and interstocks were sour orange (Citrus aurantium) and volkamer lemon (Citrus volkameriana). Whereas, the cultivars which used as a scion source was Navel orange (Citrus sinensis).

The rootstocks were six months old seedlings $70 \mathrm{~cm}$ in height for grafting, planted in plastic pots $(40 \mathrm{~cm})$ filled with 5 liters of soil mixture ( sand: peatmoss 2:1 v/v ) for each. In February 2014 the rootstocks were cleft grafted using the scions of interstocks then the same procedures were repeated in February 2015.

After that, In February 2015 the interstocks (the first season plants) were shield budded using $\mathrm{Na}$ vel orange scions on height of $20-25 \mathrm{~cm}$ of the graft union between the interstock and rootstock then the same procedures were repeated in February 2016 (the second season plants).

During the experiment, the plants were fertilized periodically using N P K compound fertilizer and sprayed with pesticides as required. The scion used as interstock was $10 \mathrm{~cm}$ in length bears 3-4 buds prepared from shoots.

\section{The experiment treatments}

1. Navel orange (N.O) buddedon sour orange (S.O) rootstock (control).

2. Navel orange (N.O) budded on volkamer lemon (V.L) rootstock (control).

3. Navel orange budded on volkamer lemon interstock which grafted on sour orange rootstock [NO/ VL/ SO (rootstock)].

4. Navel orange budded on sour orange interstock which grafted on volkamer lemon rootstock [NO/ SO / VL (rootstock)].

5. Navel orange budded on sour orange interstock which grafted on sour orange rootstock [NO/ SO / SO (rootstock)].

6. Navel orange budded on volkamer lemon interstock which grafted on volkamer lemon rootstock [NO/ VL / VL (rootstock)].

\section{Experimental design}

The treatments were completely randomized design, each treatment contained 4 replicates and each one represented by five transplants. At the end of each season (last week of September) the following parameters were measured to evaluate the tested treatment (leaf area, fresh weight and dry weight of vegetative growth and root length).

The measurements: Vegetative growth parameters

Plant height, leaf number of scion growth and stem thickness $5 \mathrm{~cm}$ above and below the graft union were measured at end season.

\subsection{Scion height $(\mathrm{cm})$}

Readings were taken from the start of union zone of scion at the end of each season for each transplant.

\subsection{Number of leaves}

The number of leaves for each transplant were counted at end of each season.

\subsection{Scion stem thickness}

Vernier Caliper was used at $5 \mathrm{~cm}$ above and below union zone in budded transplants (interstock and cultivars) and above/ below ratio was calculated at the end of each season.

\subsection{Leaf area $\left(\mathrm{cm}^{2}\right)$}

Ten leaves were collected at the end of growth seasons for each transplant then the leaf area was determine by using LI-COR, inc. Lincolr, Nebraska USA-LI-3100 area meter.

\subsection{Fresh and dry weights of shoot and root system (g)}

By the end of each season, fresh and dry weights of shoot system and roots were determined.

\section{Chemical parameters}

\subsection{Leaf mineral concentration}

Leaf mineral concentration was determined in 10 leaves for each replicate collected from 6-8 months old leaves in late September in each season. The leaf samples were washed with tap water then rinsed with distilled water, dried at $70{ }^{\circ} \mathrm{C}$ in an oven till constant weight. Samples were digested 
using sulphoric acid and hydrogen peroxide according to Parkinson and Allen (1975), Total nitrogen was determined by Micro-Kjeldahl method approved to Pregel (1945). Total phosphorus was determined by method of Trough and Mery, (1929). Potassium was determined by flame photometer according to Brown and Lilleland, (1946). Magnesium, calcium, manganese, iron and zinc were estimated by using Atomic Absorption spectrophotometer according to Cottenie (1980). Macronutrients were calculated as percentage of dry weight whereas, micronutrients as parts per million (ppm).

1.4. Scion stem and roots carbohydrates concentration, nitrogen concentration and C/Nratio

Total Carbohydrates and total nitrogenratio were calculated according to Dubois et al (1956). Total nitrogen percentage was estimated in dry matter according to Pregel (1945). Total carbohydrates were determined calorimetrically by using the potassium ferricyanide method according to Forcee (1936). C/N ratio was calculated.

\subsection{Total phenols and total indols in trans-} plants stem and root

\subsubsection{Extraction of total indoles and phenols}

One gram of fresh samples in three replicates were sectioned into minute pieces and extracted with $5 \mathrm{ml}$ cold methanol $80 \%$ and stored in cold condition for 24- $48 \mathrm{~h}$. The combined extracts were collected and filtered. Then, the volume of sample was raised up to known volume with cold methanol.

\subsubsection{Determination of total indoles}

The total indols were determined in the methanolic extract using p-dimethyl amino benzaldehyde (PDAB, $1 \mathrm{~g}$ was dissolved in $50 \mathrm{ml} \mathrm{HCl}$ conc. and $50 \mathrm{ml}$ ethanol $95 \%$ ) test according to Selim et al (1978).

\subsubsection{Determination of total phenols}

Phenols determination was carried out according to Folin and Ciocalteu (1972).

\section{Statistical analysis}

The obtained data of the experiments were statistically analyzed using the analysis of variance method according to Snedecor and Cochran (1980). Duncan's multiple range test at $5 \%$ level was used for means comparing Duncan (1955).

\section{RESULTS AND DISCUSSION}

\section{Vegetative growth parameters}

Data in Table (1) showed that scion height of Navel orange scions budded on sour orange rootstockT1,T5 andT6 achieved the highest scion height significantly compared toT4 only in the first season; While in the second season Navel orange scion budded on volkamer lemon interstock grafted on volkamer lemon rootstock (T6) was the highest significantly. Concerning Leaf number in the first season, Navel orange scion budded on sour orange rootstock ( $\mathrm{T} 1$ ) achieved the highest valuesignificantly while the second season Navel Orange scion budded on volkamer lemon interstock grafted on volkamer lemon rootstock (T6) achieved the higher significantleaf number compared to T2 and T4. While recorded dataconcerning stem thickness above graft union in the first season, Navel orange scions budded on sour orange rootstock $\mathrm{T} 1$ and T2 achieved the highest significant values, but values in the second season Navel orange scion budded on volkamer lemon rootstock (T2) achieved the best values compared to the other treatments. Regarding stem thickness below graft union in the first season; the best treatment was Navel orange scion budded on sour orange rootstock (T1) and volkamer lemon (T2) while, in the second season Navel orange scion budded on volkamer lemon rootstock (T2) achieved the best value compared to the other treatments. While above/below stem thickness ratio in the first and second seasons Navel orange scion budded on sour orange and volkamer lemon rootstock were the highest.

These results are generally agreed with those found by Zayan et al (2004) and Ibrahim (2005) who reported that scion height Navel orange on Volkamer lemon rootstock was the higher compared to other rootstocks. Also, our findings went in parallel with those of Kamilogu and Yesiloglu (2014) they reported that,Navelina orange budded on Citrumelo interstock grafted on sour orange rootstock were gave largest stem diameter of the scion. 
Table 1. Effect of interstock on scion height, leaf number and stem thickness of Navel orange transplantsscion at 2015 - 2016 and 2016-2017 seasons.

\begin{tabular}{|c|c|c|c|c|c|}
\hline \multirow[b]{2}{*}{ Treatments } & \multirow[b]{2}{*}{$\begin{array}{l}\text { Scion height } \\
\quad(\mathrm{cm})\end{array}$} & \multirow[b]{2}{*}{ Leaf number } & \multicolumn{3}{|c|}{ Stem thickness $(\mathrm{cm})$} \\
\hline & & & $\begin{array}{c}\text { Above } \\
\text { graft union }\end{array}$ & $\begin{array}{c}\text { below graft } \\
\text { union }\end{array}$ & $\begin{array}{c}\text { Above/ } \\
\text { below }\end{array}$ \\
\hline \multicolumn{6}{|c|}{ The first season(2016) } \\
\hline $\begin{array}{ll}\mathrm{T} 1 & \text { (NO/SO) }\end{array}$ & 26.91 a & $46.50 \mathrm{a}$ & $0.48 \mathrm{a}$ & $0.65 \mathrm{a}$ & $0.73 \mathrm{a}$ \\
\hline T2 (NO /VL) & $24.95 \mathrm{a}$ & $26.50 \mathrm{~cd}$ & $0.41 \mathrm{a}$ & $0.56 \mathrm{a}$ & $0.73 \mathrm{a}$ \\
\hline T3 (NO/ VL/SO) & $21.75 \mathrm{ab}$ & $35.50 \mathrm{bc}$ & $0.23 \mathrm{~b}$ & $0.45 \mathrm{~b}$ & $0.51 \mathrm{~b}$ \\
\hline T4 (NO/SO/VL) & $17.30 \mathrm{~b}$ & $23.80 d$ & $0.28 b$ & $0.41 \mathrm{~b}$ & $0.68 \mathrm{ab}$ \\
\hline T5 (NO/SO/SO) & 26.36 a & $40.50 a b$ & $0.23 \mathrm{~b}$ & $0.38 \mathrm{~b}$ & $0.60 \mathrm{ab}$ \\
\hline T6 (NO/ VL / VL) & 25.61 a & $34.00 \mathrm{bc}$ & $0.26 \mathrm{~b}$ & $0.38 \mathrm{~b}$ & $0.68 \mathrm{ab}$ \\
\hline \multicolumn{6}{|c|}{ The second season (2017) } \\
\hline $\begin{array}{ll}\mathrm{T} 1 & (\mathrm{NO} / \mathrm{SO})\end{array}$ & $24.60 \mathrm{bcd}$ & $38.00 \mathrm{ab}$ & $0.35 a b$ & $0.48 \mathrm{a}$ & $0.72 \mathrm{a}$ \\
\hline $\mathrm{T} 2 \quad(\mathrm{NO} / \mathrm{VL})$ & $24.13 \mathrm{~cd}$ & $34.30 \mathrm{~b}$ & $0.38 \mathrm{a}$ & $0.50 \mathrm{a}$ & $0.76 \mathrm{a}$ \\
\hline T3 (NO/ VL/SO) & $21.50 \mathrm{~d}$ & $37.80 \mathrm{ab}$ & $0.31 \mathrm{~b}$ & $0.36 \mathrm{~b}$ & $0.86 a$ \\
\hline T4 (NO/SO/VL) & $25.30 \mathrm{bc}$ & $29.80 \quad c$ & $0.35 a b$ & $0.45 \mathrm{a}$ & 0.77 a \\
\hline T5 (NO/SO/SO) & $27.81 b$ & $39.60 \mathrm{a}$ & $0.30 \mathrm{~b}$ & $0.36 \mathrm{~b}$ & $0.83 \mathrm{a}$ \\
\hline T6 (NO/ VL / VL) & $31.48 \quad \mathrm{a}$ & $41.50 \mathrm{a}$ & $0.31 \mathrm{~b}$ & $0.36 \mathrm{~b}$ & $0.86 \mathrm{a}$ \\
\hline
\end{tabular}

Values having the same letter(s) in each column for each season are not significantly different at 0.05 level.

Data presented in Table (2) showed that, leaf area $\left(\mathrm{cm}^{2}\right)$ in the first season Navel orange scion budded on Volkamer Lemon rootstock (T2, T1 and T4) achieved the higher significant compared to T3,T5 and T6 while in the second season leaf area Navel orange scions budded on Sour orange interstock grafted on volkamer lemon rootstock (T4) achieved the highest value compared to the other treatments. Regarding the scion vegetative growth fresh weight in the first and second season Navel orange scion budded on sour orange rootstock (T1) got the highest value significantly compared to the other treatments. Whereas the scion vegetative growth dry weight in the first season was in favor of Navel orange scion budded on sour orange rootstock (T1) which achieved the higher value significantly compared to T2 but in the second season Navel orange scion budded on sour orange rootstock(T1) gave the higher value significantly compared to T3 and T4. Root fresh weight in the first and second seasons was in favor of(T1) which gave the highest value significantly compared to most of the other treatments. Also, root dry weight in the first season was in favor of(T1 and T3) which achieved the highest but in the second season (T1)was the highest value significantly compared to the other treatments. Root length in the first season was not significantly affected by any treat- ments while in the second season, Navel orange scion budded on sour orange interstock grafted on sour orange rootstock (T5) gave the highest root length significantly compared to the other treatments.

Similar findings were recorded by Abd ElRahman 2002 he found that, leaf area of Navel orange budded on volkamer lemon rootstock was highly affected by rootstock type. Also, our findings were in contrary with those of Somaia El-Sayed, 1999 who proved that volkamer Lemon rootstock has higher values of all vegetative growth measured for Washington Navel orange than other rootstocks.

Data in Table (3) indicated that, Navel orange scion budded on volkamer lemon interstock grafted on volkamer lemon rootstock (T6) got the highest nitrogen concentration in the first season significantly compared to the other treatments but had lowest significant value in the second season. Phosphorus concentration in the first season was in favor of T1and T5 which were equal (0.11) with significant difference compared to other treatments but, in the second season Navel orange scion had insignificant difference among treatments. Potassium in the first season was in favor of T6 which gave the highest significantly compared to the other treatments except T4 while the second season 
Table 2. Effect of interstock on leaf area and fresh, dry weights of vegetative growth and roots \% and root length of Navel Orangetransplantsat 2016 and 2017seasons.

\begin{tabular}{|c|c|c|c|c|c|c|}
\hline Treatments & $\begin{array}{l}\text { Leaf } \\
\text { area } \\
\left(\mathrm{cm}^{2}\right)\end{array}$ & $\begin{array}{c}\text { Scion } \\
\text { V.g.f.w }(g)\end{array}$ & $\begin{array}{c}\text { Scion } \\
\text { V.g.d.w } \\
(\%)\end{array}$ & $\begin{array}{l}\text { Root.f.w } \\
\text { (g) }\end{array}$ & $\begin{array}{l}\text { Root.d.w } \\
(\%)\end{array}$ & $\begin{array}{c}\text { Root } \\
\text { length }(\mathrm{cm})\end{array}$ \\
\hline \multicolumn{7}{|c|}{ The first season (2016) } \\
\hline (NO/SO) & $24.62 \mathrm{a}$ & $37.61 \mathrm{a}$ & $43.89 \mathrm{a}$ & $43.59 \mathrm{a}$ & 50.49 a & $37.83 \mathrm{a}$ \\
\hline T2 (NO /VL) & 24.78 a & $16.94 \mathrm{c}$ & $29.50 \mathrm{~b}$ & $20.96 \mathrm{~b}$ & $42.94 \mathrm{~b}$ & $32.26 \mathrm{a}$ \\
\hline T3 (NO/ VL/SO) & $16.91 \mathrm{c}$ & $14.03 \mathrm{~d}$ & $43.04 \mathrm{a}$ & $22.48 \mathrm{~b}$ & $51.69 \mathrm{a}$ & $43.13 \mathrm{a}$ \\
\hline T4 (NO/SO/VL) & $23.55 \mathrm{a}$ & $10.05 \mathrm{e}$ & $43.86 \mathrm{a}$ & $24.43 \mathrm{~b}$ & $38.38 \mathrm{c}$ & $34.43 \mathrm{a}$ \\
\hline T5 (NO/SO/SO) & $21.35 b$ & $19.15 b$ & $43.30 \mathrm{a}$ & $31.57 \mathrm{ab}$ & $44.14 \mathrm{~b}$ & $34.80 \mathrm{a}$ \\
\hline T6 (NO/ VL / VL) & $18.16 \mathrm{c}$ & $14.55 \mathrm{~d}$ & $30.23 \mathrm{~b}$ & $31.09 a b$ & $43.02 \mathrm{~b}$ & $34.93 \mathrm{a}$ \\
\hline \multicolumn{7}{|c|}{ The second season (2017) } \\
\hline (NO/SO) & $28.80 a b$ & $38.80 \quad \mathrm{a}$ & $51.84 \quad \mathrm{a}$ & $38.08 \mathrm{a}$ & 50.38 a & $33.94 \mathrm{ab}$ \\
\hline T2 (NO /VL) & $29.51 \mathrm{a}$ & $18.05 \mathrm{bc}$ & $45.17 \mathrm{ab}$ & $25.73 \mathrm{c}$ & $44.24 \mathrm{~b}$ & $28.42 \mathrm{c}$ \\
\hline T3 (NO/ VL/SO) & $18.06 \mathrm{c}$ & $19.17 \mathrm{bc}$ & $41.35 \mathrm{~b}$ & $29.35 \mathrm{bc}$ & $45.67 b$ & $28.92 \mathrm{c}$ \\
\hline T4 (NO/SO/VL) & $29.80 \mathrm{a}$ & $14.45 \mathrm{c}$ & $41.04 \mathrm{~b}$ & $28.25 \mathrm{c}$ & $43.66 \mathrm{~b}$ & $31.11 \mathrm{bc}$ \\
\hline T5 (NO/SO/SO) & $26.33 \mathrm{~b}$ & $23.22 b$ & $47.21 \mathrm{ab}$ & $35.92 a b$ & $45.17 \quad b$ & 34.98 a \\
\hline T6 (NO/ VL / VL) & $27.66 \mathrm{ab}$ & $15.19 \mathrm{c}$ & $46.03 \mathrm{ab}$ & $26.73 \mathrm{c}$ & $44.03 \mathrm{~b}$ & $31.00 \mathrm{bc}$ \\
\hline
\end{tabular}

Values having the same letter(s) in each column for each season are not significantly different at 0.05 level

Table 3. Effect of interstock on leaf macro elements concentration of Navel orangetransplants at 2016 and2017 seasons.

\begin{tabular}{|c|c|c|c|c|c|}
\hline Treatments & $\mathrm{N}$ & $P$ & $\mathrm{~K}$ & $\mathrm{Ca}$ & $\mathrm{Mg}$ \\
\hline \multicolumn{6}{|c|}{ The first season (2016) } \\
\hline T1 $\quad$ (NO/SO) & $2.63 \mathrm{~b}$ & $0.11 \mathrm{a}$ & $0.96 \mathrm{~d}$ & $3.13 \mathrm{a}$ & $0.72 \mathrm{a}$ \\
\hline T2 (NO/VL) & $2.64 \mathrm{~b}$ & $0.09 \mathrm{~b}$ & $1.15 \mathrm{c}$ & $2.36 \mathrm{c}$ & $0.20 \mathrm{c}$ \\
\hline T3 (NO/ VL/SO) & $2.30 \mathrm{~d}$ & $0.08 \mathrm{~b}$ & $1.21 \mathrm{c}$ & $3.13 \mathrm{a}$ & $0.34 \mathrm{~b}$ \\
\hline T4 (NO/SO/VL) & $2.66 \mathrm{~b}$ & $0.08 \mathrm{~b}$ & $1.60 a b$ & $2.16 \mathrm{~d}$ & $0.46 \mathrm{~b}$ \\
\hline T5 (NO/SO/SO) & $2.50 \mathrm{c}$ & $0.11 \mathrm{a}$ & $1.52 \mathrm{~b}$ & $2.83 \mathrm{~b}$ & $0.49 \mathrm{~b}$ \\
\hline T6 (NO/ VL / VL) & $2.77 \mathrm{a}$ & $0.09 \mathrm{~b}$ & $1.68 \mathrm{a}$ & $2.46 \mathrm{c}$ & $0.37 \mathrm{~b}$ \\
\hline \multicolumn{6}{|c|}{ The second season (2017) } \\
\hline $\begin{array}{ll}\mathrm{T} 1 & \text { (NO/SO) }\end{array}$ & $2.50 \mathrm{ab}$ & $0.13 \mathrm{a}$ & $1.35 \mathrm{a}$ & $3.70 a b$ & $0.63 \mathrm{~b}$ \\
\hline T2 (NO / VL) & $2.50 \mathrm{ab}$ & $0.14 a$ & $1.44 \mathrm{a}$ & $3.03 \mathrm{c}$ & $0.44 \mathrm{c}$ \\
\hline T3 (NO/ VL/SO) & $2.63 \mathrm{~b}$ & $0.12 \mathrm{a}$ & $1.33 \mathrm{a}$ & 3.83 a & $0.36 \mathrm{c}$ \\
\hline T4 (NO/SO/VL) & $2.66 \mathrm{ab}$ & $0.12 \mathrm{a}$ & $1.48 \mathrm{a}$ & $2.70 \mathrm{c}$ & $0.61 \mathrm{~b}$ \\
\hline T5 (NO/SO/SO) & $2.60 \mathrm{ab}$ & $0.16 \mathrm{a}$ & $1.33 \mathrm{a}$ & $3.63 a b$ & $0.86 a$ \\
\hline T6 (NO/ VL / VL) & $2.80 \quad a$ & $0.17 \mathrm{a}$ & $1.48 \mathrm{a}$ & $3.23 \mathrm{bc}$ & $0.91 \mathrm{a}$ \\
\hline Standard level & $2.4-2.6 \%$ & $0.12-0.16 \%$ & $0.70-1.09 \%$ & $3-5.5 \%$ & $0.26-0.96 \%$ \\
\hline
\end{tabular}

Values having the same letter(s) in each column for each season are not significantly different at 0.05 level.

not significantly affected by any treatments. Calcium in the first season, T1and T3gave the highest significant value but in the second season Navel orange scion budded on volkamer lemon interstock grafted on sour orange rootstock (T3) was the highest significant compared to the other treatments except T1 and T5. Regarding magnesium concentration in Navel orange scion leaves; Navel orange scion budded on Sour Orange rootstock(T1)accomplished the highest significantly value in the first season compared to the other treatments but in the second season, the highest concentration of $\mathrm{Mg}$ was in favor of was T6 followed by T5 significantly compared to the other treatments.

The obtained results indicated that Navel orange scion leaves on Volkamer Lemon rootstock had the highest levels of N, P, K, Ca and Mg concentration in their leaves compared with other rootstocks, on the same trend; Faiz et al (1993) 
and Somaia El-Sayed (2008) reported that Washington Navel orange budded on volkamer lemon rootstock had significantly higher $\mathrm{N}, \mathrm{K}$ and $\mathrm{Mg}$.

Available data in Table (4), Iron in showed that it was in favor of the first season T3,T4 and T6 which gave the highest values significantly compared to the other treatments while in the second season T3 and T6 achieved the highest values significantly. Zinc in the first season was in favor of T3, T4 and T6 which gave the highest values significantly but the second season T6 had the higher value significantly compared to $\mathrm{T} 1$ only. Manganese T4 showed highest value significantly whereas in the second season T6 had the highest value significantly compared to the other treatments.

Our findings went in parallel with those of Fallahi and Rodney (1992) who reported that, Fairchild mandarin budded on volkamer lemon rootstock gave highest levels of Fe and $\mathrm{Zn}$ content in leaf.

Table 4. Effect of interstock on leaf micro elements concentration of Navel Orange transplants at 2016 and2017 seasons.

\begin{tabular}{|c|c|c|c|}
\hline Treatment & $\mathrm{Fe}$ & $\overline{Z n}$ & $\overline{M n}$ \\
\hline \multicolumn{4}{|c|}{ The first season (2016) } \\
\hline T1 $\quad$ (NO/SO) & $179.33 \mathrm{bc}$ & $24.80 c$ & $152.66 \mathrm{e}$ \\
\hline T2 (NO/VL) & $167.93 c$ & $31.06 \mathrm{~b}$ & $148.00 \mathrm{c}$ \\
\hline T3 (NO/ VL/SO) & $239.66 a$ & $35.00 \mathrm{a}$ & $171.33 \mathrm{~d}$ \\
\hline T4 (NO/SO/VL) & $248.40 a$ & $34.46 \mathrm{a}$ & $246.00 \quad a$ \\
\hline T5 (NO/SO/SO) & $183.93 b$ & $25.93 c$ & $152.00 \mathrm{e}$ \\
\hline T6 (NO/ VL / VL) & $250.26 a$ & $36.00 \mathrm{a}$ & $216.66 \quad b$ \\
\hline \multicolumn{4}{|c|}{ The second season (2017) } \\
\hline $\begin{array}{ll}\mathrm{T} 1 & \text { (NO/SO) }\end{array}$ & 187 & $25.10 \mathrm{~b}$ & $114.00 \mathrm{~b}$ \\
\hline T2 (NO/VL) & $173.43 c$ & $27.00 \mathrm{ab}$ & $136.66 \mathrm{~b}$ \\
\hline T3 (NO/ VL/SO) & $250.63 a$ & $33.46 \mathrm{ab}$ & $135.33 b$ \\
\hline T4 (NO/SO/VL) & $227.43 a b$ & $32.10 a b$ & $156.66 b$ \\
\hline T5 (NO/SO/SO) & $191.40 \mathrm{bc}$ & $28.20 \mathrm{ab}$ & $158.00 \mathrm{~b}$ \\
\hline T6 (NO/ VL / VL) & $242.06 a$ & $34.81 a$ & $212.66 a$ \\
\hline Standard level & $\begin{array}{c}60-200 \\
\text { ppm }\end{array}$ & $\begin{array}{c}20-100 \\
\text { ppm }\end{array}$ & $\begin{array}{c}25-200 \\
\text { ppm }\end{array}$ \\
\hline
\end{tabular}

Values having the same letter(s) in each column for each season are not significantly different at 0.05 level.

Data in Table (5) showed that, in the first seasontotal carbohydrates of Navel orange scion stem budded on volkamer lemon interstock grafted on sour orange rootstock (T3) was the highest value significantly compared to the other treatments. Whereas the second season, T3, T4 and T5 were the highest treatments in carbohydrates content significantly. Total nitrogen in scion stem in the first season was in favor of T5 which gave highest value significantly compared to the other treatments while the second season, T6 was the highest value significantly compared to the other treatments. $\mathrm{C} / \mathrm{N}$ ratio in scion stem in both two seasons was in favor of T3which gave the highest value significantly compared to the other treatments.

In this trend, Manal Abo-Eid et al (2010) found that Baladi lime budded on troyarcitrange got on the greatest value of total carbohydrates followed by that budded on sour orange rootstock. While, Baladi lime budded on volkamer lemon rootstock gave the lowest values.

Table 5. Effect of interstock on total carbohydrates, total nitrogen and $\mathrm{C} / \mathrm{N}$ ratio in scion stem of Navel Orange transplants at 2016 and2017 seasons.

\begin{tabular}{|c|c|c|c|}
\hline Treatments & $\begin{array}{c}\text { Total carbohy- } \\
\text { drates } \\
(\mathrm{mg})\end{array}$ & $\begin{array}{l}\text { Total nitro- } \\
\text { gen } \\
(\%)\end{array}$ & $\begin{array}{l}\mathrm{C} / \mathrm{N} \\
\text { ratio }\end{array}$ \\
\hline \multicolumn{4}{|c|}{ The first season (2016) } \\
\hline T1 (NO/SO) & $22.64 b$ & $0.88 b$ & $25.96 \mathrm{~cd}$ \\
\hline T2 (NO/VL) & $19.39 c$ & $0.70 c$ & $27.61 \mathrm{bc}$ \\
\hline T3 (NO/ VL/SO) & $44.99 a$ & $0.73 c$ & $59.82 a$ \\
\hline T4 (NO/SO/VL) & $24.17 \mathrm{~b}$ & $0.77 \mathrm{bc}$ & $31.53 b$ \\
\hline $\mathrm{T} 5(\mathrm{NO} / \mathrm{SO} / \mathrm{SO})$ & $24.45 b$ & $1.16 \mathrm{a}$ & $20.96 d$ \\
\hline $\mathrm{T} 6$ (NO/ VL / VL) & $19.02 \mathrm{c}$ & $0.82 \mathrm{bc}$ & $22.85 \mathrm{~cd}$ \\
\hline \multicolumn{4}{|c|}{ The Second season (2017) } \\
\hline T1 $\quad$ (NO/SO) & $18.42 \mathrm{c}$ & $0.70 \mathrm{bc}$ & $26.53 c$ \\
\hline T2 (NO/VL) & $18.08 \mathrm{c}$ & $0.66 \mathrm{bc}$ & $27.26 \mathrm{c}$ \\
\hline T3 (NO/ VL/SO) & $26.20 a$ & $0.53 \mathrm{c}$ & $48.05 a$ \\
\hline T4 (NO/SO/VL) & $24.53 a$ & $0.60 \mathrm{bc}$ & 41.49ab \\
\hline $\mathrm{T} 5$ (NO/SO/SO) & $25.64 a$ & $0.76 a b$ & $33.58 \mathrm{bc}$ \\
\hline $\mathrm{T} 6(\mathrm{NO} / \mathrm{VL} / \mathrm{VL})$ & $21.13 b$ & $0.93 a$ & $23.05 c$ \\
\hline
\end{tabular}

Values having the same letter(s) in each column for each season are not significantly different at 0.05 level

Data recorded in Table (6) showed that, (T1) achieved the highest total carbohydrates in root in the first season significantly compared to the other treatments except T6 whereas; in the second season T6 achieved the highest value significantly compared to the other treatments. Total nitrogen in root in the first season T1 gave the higher content significantly compared to the other treatment while in the second season T6 had the highest content significantly compared to $\mathrm{T} 2$ and $\mathrm{T} 3$. $\mathrm{C} / \mathrm{N}$ ratio in root in the first season showed in favor of T2 and T6 which gave the highest percentage significantly but in the second season T1, T2 and T3 were the 
highest percentage significantly compared to the other treatments except T6.

Table 6. Effect of interstock on total carbohydrates and total nitrogen and $\mathrm{C} / \mathrm{N}$ ratio in the roots of $\mathrm{Na}$ vel orange transplants at 2016 and 2017 seasons.

\begin{tabular}{|c|c|c|c|}
\hline Treatments & $\begin{array}{c}\text { Total carbohy- } \\
\text { drates } \\
(\mathrm{mg})\end{array}$ & $\begin{array}{c}\text { Total nitro- } \\
\text { gen } \\
(\%)\end{array}$ & $\begin{array}{l}\mathrm{C} / \mathrm{N} \\
\text { ratio }\end{array}$ \\
\hline \multicolumn{4}{|c|}{ The first season (2016) } \\
\hline T1 $\quad$ (NO/SO) & $122.45 \mathrm{a}$ & $0.98 \mathrm{a}$ & $127.10 \mathrm{~b}$ \\
\hline T2 (NO /VL) & $111.54 \mathrm{~b}$ & $0.73 \mathrm{c}$ & $154.60 \mathrm{a}$ \\
\hline T3 (NO/ VL/SO) & $80.16 \mathrm{c}$ & $0.89 a b$ & $91.92 \mathrm{c}$ \\
\hline T4 (NO/SO/VL) & $64.25 \mathrm{~d}$ & $0.89 a b$ & $71.23 \mathrm{~d}$ \\
\hline T5 (NO/SO/SO) & $44.88 \mathrm{e}$ & $0.88 \mathrm{ab}$ & $50.58 \mathrm{e}$ \\
\hline T6 (NO/ VL / VL) & $118.41 \mathrm{ab}$ & $0.80 \mathrm{bc}$ & $155.64 \mathrm{a}$ \\
\hline \multicolumn{4}{|c|}{ The Second season (2017) } \\
\hline T1 $\quad$ (NO/SO) & $108.21 \mathrm{~b}$ & $0.76 \mathrm{abc}$ & $141.78 \mathrm{a}$ \\
\hline $\mathrm{T} 2 \quad(\mathrm{NO} / \mathrm{VL})$ & $108.28 b$ & $0.63 \mathrm{bc}$ & $176.02 \mathrm{a}$ \\
\hline T3 (NO/ VL/SO) & $79.33 \mathrm{c}$ & $0.53 \mathrm{c}$ & $163.30 \mathrm{a}$ \\
\hline T4 (NO/SO/VL) & $62.00 \mathrm{~d}$ & $0.73 a b c$ & 86.2 bc \\
\hline T5 (NO/SO/SO) & $53.45 \mathrm{e}$ & $0.80 \mathrm{ab}$ & $67.50 \mathrm{c}$ \\
\hline T6 (NO/ VL / VL) & $120.50 \mathrm{a}$ & $0.90 \mathrm{a}$ & $134.99 a b$ \\
\hline
\end{tabular}

Values having the same letter(s) in each column for each season are not significantly different at 0.05 level.

The results are in Table (7) indicated that, T4 had the highest total indols in scion stem in the first season significantly compared to the other treatments. While, the second season T4 and T5 were the highest values significantly compared to the other treatments. Total phenols in scion stem in the first season, T4, T5 and T6 gave the highest content significantly but in the second season was T6 recorded the higher value significantly compared to T1, T2 and T5 treatments. Indols/phenols ratio in scion stem in the first season T1, T4 and T5had the higher values significantly then T6. while in the second season, T1 and T5 showed the highest values significantly compared to T6 treatment.

Abo-Eid Manal et al 2010 at this matter, Baladi lime budded on volkamer lemon rootstock had the highest content of total indols and indols/ phenols ratio in vegetative system significantly compared with rangpur lime, sour orange and toyercitrange.

Data in Table (8) reported that, total indols in root system in the first season was the highest in T1 significantly compared to the other treatments. While in the second season, T5 was the highest content significantly compared to the other treat- ments except T6. Total phenols in roots in the first and second seasons were in favor of T2 which gave the highest value significantly compared to the other treatments. Indols / phenols ratio in root in the first season were the highest significantly in T3 compared to the other treatments but in the second season, T3, T5 and T6 had higher significant value Indols / phenols ratio.

Table 7. Effect of interstock on total indols, total phenols and indols /phenols ratio in vegetative growth of Navel orange transplants at 2016 and 2017seasons.

\begin{tabular}{|c|c|c|c|}
\hline Treatment & $\begin{array}{l}\text { Total in- } \\
\text { dols }(\mathrm{mg})\end{array}$ & $\begin{array}{c}\text { Total phe- } \\
\text { nols } \\
(\mathrm{mg})\end{array}$ & $\begin{array}{c}\text { Indols/ } \\
\text { phenols } \\
\text { ratio }\end{array}$ \\
\hline \multicolumn{4}{|c|}{ The first season (2016) } \\
\hline $\mathrm{T} 1 \quad$ (NO/SO) & $0.247 \mathrm{~d}$ & $0.73 \mathrm{c}$ & $0.334 \quad a$ \\
\hline T2 $\quad$ (NO /VL) & $0.312 \mathrm{~cd}$ & $1.03 \mathrm{~b}$ & $0.301 \mathrm{ab}$ \\
\hline T3 (NO/ VL/SO) & $0.345 \mathrm{bc}$ & $1.12 \mathrm{~b}$ & $0.308 \mathrm{ab}$ \\
\hline T4 (NO/SO/VL) & $0.487 \quad a$ & $1.37 \mathrm{a}$ & 0.356 a \\
\hline T5 (NO/SO/SO) & $0.422 a b$ & $1.29 \mathrm{a}$ & $0.327 \quad a$ \\
\hline T6 (NO/ VL / VL) & $0.334 \mathrm{c}$ & $1.39 \mathrm{a}$ & $0.204 \mathrm{~b}$ \\
\hline \multicolumn{4}{|c|}{ The Second season (2017) } \\
\hline $\mathrm{T} 1 \quad(\mathrm{NO} / \mathrm{SO})$ & $0.293 \mathrm{c}$ & $0.75 \mathrm{c}$ & 0.393 a \\
\hline T2 $\quad$ (NO /VL) & $0.286 \mathrm{c}$ & $0.88 \mathrm{bc}$ & $0.343 \mathrm{ab}$ \\
\hline T3 (NO/ VL/SO) & $0.333 \mathrm{~b}$ & $1.03 \mathrm{abc}$ & $0.327 \mathrm{ab}$ \\
\hline T4 (NO/SO/VL) & $0.390 \mathrm{a}$ & $1.17 \mathrm{ab}$ & $0.333 \mathrm{ab}$ \\
\hline T5 (NO/SO/SO) & 0.406 a & 1.15 & 0.363 a \\
\hline T6 (NO/ VL / VL) & $0.323 \mathrm{~b}$ & $1.28 \quad \mathrm{a}$ & $0.253 \mathrm{~b}$ \\
\hline
\end{tabular}

Values having the same letter(s) in each column for each season are not significantly different at 0.05 level

\section{REFERENCES}

Abd-El-Rahman, A.M. 2002. Response of Navel orange trees to sour orange and volkamer lemon rootstocks under alluvial soil condition. Annals of Agricultural Science, Moshtohor, 40(2), 1149-1158.

Agricultural Export Council of Egypt 2017. http://www.aecegypt.com/WebPages Ar/Com mon/Home.aspx.

Bassal, M.A. 2008. Growth yield and fruit quality of "Marisol" Clementine grown on four rootstock in Egypt. Science Horticulture, 1 19(2)132-137. 
Brown, J.D. and Lilleland, O. 1946 Uptake determination of potassium and sodium in plant material and soil extract by flam photometry. Proc. Am. Soc., 48, 341-346.

Castle, W.S. 2010. A career perspective on Citrus rootstock, their development, and commercialization. Hort. Science 45(1), 11-15.

Cottenie, A. 1980. Soil and plant testing as a basis of fertilizer recommendation. FAO Soil Bull., 38/2.

Dubois, M., Gilles K., Hamilton J.K. and Rebersand P.A.F. Smith 1956. Acolorimetric method for the determination of sugars and related substances. Anal. Chem. 28, 350-356.

Duncan, D.B. 1955. Multiple range and multiple F tests. Biometrics, 11, 1-42.

Faiz. G.N., Saad-Allah M.H. and Guindy L.F. 1993. Growth of some citrus rootstock seedlings under condition of sandy soil and saline drip irrigation. Egypt. J. AUDI. Sci., 8(5), 405422.

Fallahi, E. and Rodeny D.R. 1992. Tree size, yield, fruit quality and leaf mineral nutrient concentration of Fairchild mandarin on six rootstocks. J. Amer. Soc. Hort. Sci., 114(2), 187190.

Ferguson L., Elliot E. and Cardwell G. 2014. Citrus Production Manual. University of California Agriculture and Natural Resources UCANR Publication, 3539, pp. 69-83.

Folin, O. and Ciocalteu V., 1972. On tyrosine and tryptophane determination in proteins. Journal Bio. Chem., 27, 627-650.

Forcee, W.T. 1936. Determination of sugars in plant materials, a photpcalorimetric method, Indust. Chem. Anal. 10, 411-418.

Gemino, V., Syvertsen G.P., Simon I., Martinez V., Camra-zapata G.M., Nieves M. and Sanchez F.G. 2012. Interstock of 'Valencia' orange affects the flooding tolerance in ' Verna' lemon trees. Hort. Science 47(3), 403-409.

Hudson, T.H., Kaster D.E. and Davies F.T. and Geneve R.L. 2014. Plant propagation principles and practices. The $11^{\text {th }}$ Ed., PrenticeHall International, Inc., pp. 418-422.

Ibrahim, A.M. 2005. Mutual effects of some citrus rootstocks with Valencia orange and Baladi mandarin under Ismailia governorate condition. Ph.D. Thesis Fac. Agric. Ain shams Univ. Cairo, Egypt, pp. 29-35.

Izquierdo, A.G., Riquelme M.T., Porras I. and Ferreres F. 2004. Effect of rootstock and interstock grafted in lemon tree (Citrus lime L.)
Burm) on the flavonoid content of lemon juice. J. Agric. Food Chem., 52. 324-331.

Kamilogu. U.M. and Yesiloglu T. 2014 Effect of Interstocks In Photosynthesis and Growth Rates for 'Navelina' orange and 'Kütdiken' lemon. Turkish Journal of Agricultural and Natural Sciences. Special Issue, 1, 939-946.

Khankahdani, H.H., Hasanpour A. and Aboutalebi, A. 2006. Effects of different rootstocks on vegetative growth, dry mater and mineral concentration of Mexican lime (Citrus aurantifoliar Swingle). Seed and plant. 22(2), 155-166.

Parkinson, J.A. and Allen S.E. 1975. A wet oxidation procedure suitable for the determination of nitrogen and mineral nutrients in biological material. Common Soil Sci. and Plant Analysis, 6(1), 1- 11.

Pregl, E. 1945. Quantitative Organic Micro Analysis. $4^{\text {th }}$ Ed. Chundril, London, UK.

Protopapadakis, E., Voulgaropoulos A. and Sofoniou 1998.Rootstocks affect leaf and fruit mineral concentrations of Washington Navel orange fruits. Paris, 53(3), 167-173.

Manal Abo-Eid, Abou-Rawash M., El-Gazzar A. and El-Wakeel H. 2010. Effect of some Citrus rootstocks on vegetative growth and leaf mineral content of Balady lime transplants. J. Biol. Chem. Environ. Sci., 5(4), 129-141.

Manal Abo-Eid, El-Wakeel H., El-Gazzar A. and Saed, R.A. 2017. Effect of different levels of nitrogen and potassium on growth and productivity of Tangarin cv. Murcott budded on Sour orange and Volkamer rootstock. Ph.D. Thesis Fac. Agric. Ain Shams Univ., Cairo, Egypt, pp. 21-24.

Selim, H.H., Fayek M.A. and Sewidan A.M. 1978. Reproduction of Bircherapple cultivar by layering. Annals of Agric. Sci. Moshtohor, 9, 157165.

Shafieizargar, A., Awang Y., Juraimi A. and Othman R. 2012. Yield and fruit quality of "Queen" orange [Citrus sinensis (L.) Osb.] grafted on different root stocks in Iran, AJCS 6(5),777- 783.

Sharma, R.M., Dubey A.K.. Awasthi O.P. and Kaur C. 2016. Growth, yield, fruit quality and leaf nutrient status of grapefruit(Citrus paradise Macf): variation from rootstocks. Scientia Horticulture, 210, 41-48.

Snedecor, G.W. and Cochran W.G. 1980 Statistical Methods. $6^{\text {th }}$ Ed. 507p. lowa State Univ. Press, Amer. lowa, U.S.A.

Somaia El-Sayed,. A. 1999. Physiology studies on some orange varieties budded on differ- 
ent rootstocks. Ph.D.Thesis, Fac. Agric., Tanta Univ., Egypt.

Somaia El-Sayed, A. 2008. Nutritional status of different parts of tree and fruit of Washington Navel orange as affected by five different rootstocks. Hort. Minufiya J. Agric. Res. 33(3), 797-809.
Truog, E. and Meyer A.H. 1929. Improvements in the denies colorimetricmethod for phosphorus and arsenic. Ind. Eng. Chem. Anal. 1 (3), 136139.

Zayan, M.A., Zeerban S.M., Ayaad H.M., Dawood S.A. and Ennab H.A. 2004. Evaluation study on Washington Navel orange cultivar buddedon five rootstocks. J. Agric. Res. Univ., $30(2), 400-420$. 

تأثير الاصل الوسطي على النمو والمحتوى المعدني لاوراق شتّلات البرتقال بسره

مروه محمد يحيى - حسن محمد الوكيل - مينا سمعان فرج سمعان - أسامه حلمي الجمال

$$
\text { 1 }
$$

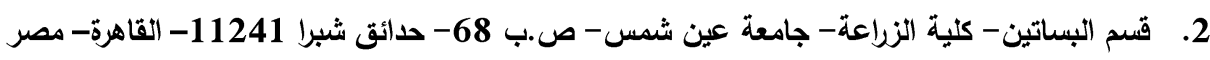

"Corresponding author: Marwayehia83@gmail.com

Received 27 February, 2019, $\quad$ Accepted 2 April, 2019

وقد أثشارت نتائج الدراسـة الى تفوق المعامله السادسـة

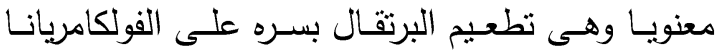

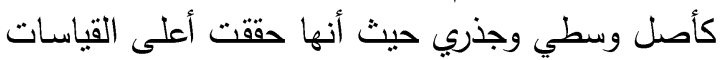

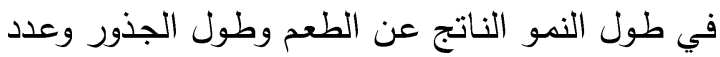

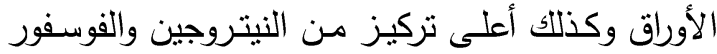

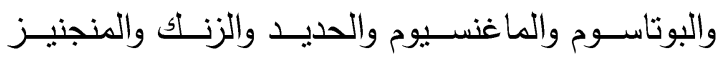
والفينولات في الطعم علاوه على ذللك حققت أعلى قيمة والئمة للكربوهيدرات في الجذور معنويا.

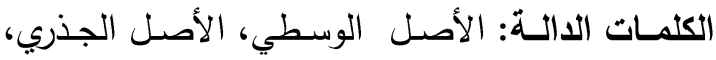
برتقال بسرة، شتلات موالح، نارنج، فولكامريانا

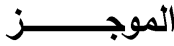

فــي هـــهـ الدراســة أســتخدم أصــلي (النـــارنج

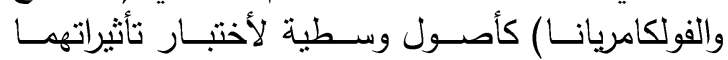
التبادلية على كل من الأصل و الطعم في مرحلة أنتاج الثتلات؛ وقد تم تقدير مواصفات النمو الخض الندري الناتج

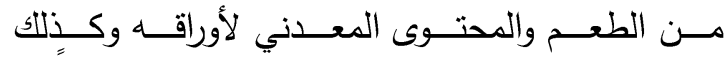
الكربوهيدرات والاتدولات والفينولات الكلية. وأيضـا تم تقدير صفات الأصل الجذري والمحتوى من النيتروجين والاتين

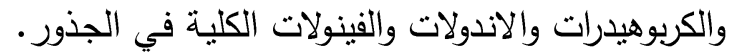

